\title{
Tingkat Efektivitas Penyembuhan Luka Bakar Derajat IIA dengan Pemberian Madu dan Pemberian Salep Nebacetin pada Tikus Putih (Rattus Norvegicus)
}

\author{
Hendy $^{1}$, I Nyoman Erlich Lister ${ }^{2}$ \\ Fakultas Kedokteran, Universitas Prima Indonesia \\ Jl. Belanga No. 1 simp. Ayahanda 20112 \\ hendysujanto18@yahoo.co.id
}

\begin{abstract}
Abstrak
Madu diduga berperan sebagai anti bakteri dan saat ini sudah dimanfaatkan sebagai penanganan korban luka bakar. Penelitian ini bertujuan membandingkan tingkat kesembuhan luka bakar dengan pemberian madu dan nebacetin topikal. Pada penelitian menggunakan 25 ekor tikus jantan Rattus Norvegicus dijadikan subyek penelitian dengan menggunakan eksperimental laboratorik dengan metode pos test only control group design. Tikus dibagi menjadi 5 kelompok secara random yaitu: K1 (Kontrol), K2 (Madu 1x1), K3 (Madu 3x1), K4 (Nebacetin Topikal Gel 5gr 1x1), K5 (Nebacetin Topikal 5gr $3 \times 1)$ dan dilakukan 15 hari pengamatan. Sebelum perlakuan tikus dibius dengan menggunakan ketamin $1 \mathrm{ml}$ yang dicampur dengan $\mathrm{NaCl} 10 \mathrm{ml}$ secara injeksi. Hasil penelitian luka bakar pada kulit tikus menunjukan kesembuhan kulit pada K1, K2, K3, K4, dan K5 adalah K1 sembuh pada hari ke-13, K2 sembuh (keropeng terlepas) pada hari ke-7, K3 sembuh (keropeng terlepas) pada hari ke-10, K4 sembuh (keropeng terlepas) pada hari ke-9, K5 sembuh (keropeng terlepas) pada hari ke-11. Simpulan, madu dapat dijadikan sebagai obat alternatif pada luka bakar sebagai pengganti antibiotik nebacetin topikal, terutama di daerah terpencil.
\end{abstract}

Kata kunci: Luka Bakar, Madu, dan Nebacetin topical $5 g$

\begin{abstract}
Honey is thought to play an antibacterial role and is currently being used as a treatment for burn injuries. This study aims to compare the rate of burn wound healing with topical administration of honey and nebacetin. In the study using 25 male rats, Rattus Norvegicus was used as the research subject. Rats were divided into 5 groups randomly, namely: K1 (Control), K2 (Honey 1x1), K3 (Honey 3x1), K4 (Nebacetin Topical Gel 5gr 1x1), K5 (Nebacetin Topical Gel 5gr 3x1) and carried out 15 days of observation. Before treatment the mice were anesthetized using $1 \mathrm{ml}$ ketamine mixed with $10 \mathrm{ml} \mathrm{NaCl}$ by injection. From the results of the study incision wounds on the skin of mice showed healing of skin in $K 1, K 2, K 3, K 4$, and $K 5, K 1$ recovered on day $13, K 2$ recovered on day $7, K 3$ recovered on day $10, K 4$ recovered on day 9, K5 recovered on on day 11. Conclusion, honey can be used as an alternative drug in burn wounds as a substitute for topical nebacetin antibiotics, especially in remote areas.
\end{abstract}

Keywords: Burn wound, Honey, and Nebacetin topical gel $5 g$ 


\section{Pendahuluan}

Luka bakar sampai saat ini merupakan salah satu masalah yang menimbulkan mordibitas dan mortalitas yang tinggi di masyarakat. Insidensi yang paling tinggi terjadi di lingkungan rumah tangga dimana derajat II menjadi yang paling sering terjadi ${ }^{1}$.

Penyebab luka bakar berdasarkan catatan America Burn Association National Burn Repository 2011 menyebutkan bahwa sebagian besar pasien luka bakar di dunia disebabkan 44\% kobaran api, 33\% air mendidih, 9\% kontak dengan sumber api, 4\% gangguan arus listrik pada alat elektronik, dan 3\% karena penggunaan zat-zat kimia misalnya obat bius dan alkohol ${ }^{2}$.

Pada umumnya, penanganan luka bakar dapat menggunakan berbagai macam bentuk obat untuk membantu proses penyembuhan luka bakar seperti bioplacenton, silver sulfadiazine, dan bacitracin sebagai agen antimikroba. Namun obat-obatan tersebut tergolong mempunyai harga yang relatif mahal, sehingga masyarakat lebih tertarik dengan obat-obatan yang berasal dari alam ${ }^{3}$. Salah satu contoh obat-obatan dari alam yang mungkin menjadi alternatif pengobatan luka bakar adalah madu.

Menurut Mundo dkk., (2004), bahwa perkembangan bakteri pathogen seperti Escherichia coli, dan Staphylococcus aureus dapat dihambat oleh pemberian madu ${ }^{4}$. Madu juga dapat dipakai sebagai terapi alami untuk luka bakar, infeksi, dan luka gesek. Dunia kedokteran modern saat ini sudah banyak menguji madu sebagai obat yang unggul ${ }^{5}$. Selain mempunyai efek anti mikroba, madu juga punya efek anti inflamasi dan menaikkan fibroblastik serta angioblastik ${ }^{6}$. Analisis tentang kandungan dalam madu mengatakan unsur terbesar komponen madu adalah glukosa dengan kadar fruktosa paling besar $(76,8 \%)^{7}$.

Madu telah terbukti dapat mempercepat penyembuhan luka. Efek percepatan luka madu ini dominan disebabkan oleh kadar gula yang tinggi akan menghambat bakteri beraktivitas sehingga bakteri tersebut mati dan tidak bisa berkembang ${ }^{8}$. Madu juga memiliki $\mathrm{pH}$ yang rendah dengan angka sekitar 3,6 sampai 3,7 yang dapat mencegah terjadinya penetrasi dan kolonisasi pada kuman. Kandungan gula yang tinggi pada madu yang dapat membuat kondisi luka menjadi lembap dan ini akan membuat luka cepat sembuh.

Tujuan penelitian ini adalah untuk mengetahui efektivitas tingkat penyembuhan luka bakar derajat dua A antara madu dan obat topikal.

\section{Metode}

Penelitian ini menggunakan penelitian eksperimental laboratorium dengan metode posttest only group design yang dilakukan di Fakultas Ilmu Pengetahuan Alam Department Biologi Universitas Sumatera Utara yang dimulai pada bulan Januari 2019. Alat dan bahan yang dipakai dalam penelitian ini Madu yang diperoleh dari daerah Kota Depok, Jawa Barat. Nebacetin Topikal 5gr, Ketamin $1 \mathrm{ml}$ dan $\mathrm{NaCl}$ 10ml diperoleh dari Kota Medan, Sumatera Utara sedangkan objeknya adalah tikus putih (Rattus Norvegicus) yang diperoleh di Animal House Fakultas Ilmu Pengetahuan Alam Universitas Sumatera Utara, Kota Medan, Sumatera Utara. 
Hendy, I Nyoman Erlich Lister. Tingkat Efektivitas Penyembuhan Luka Bakar Derajat IIA dengan Pemberian Madu dan Pemberian Salep Nebacetin pada Tikus Putih (Rattus Norvegicus)

DOI:

Tikus putih yang berusia antara 8 minggu sampai 10 minggu sebelum dilakukan perlakuan akan diadaptasi selama 7 hari. Tikus dilakukan pembiusan dengan menggunakan ketamin $1 \mathrm{ml}$ yang sudah dicampur dengan $\mathrm{NaCl}$ 10ml. Tikus putih tersebut dilakukan pencukuran bulu dan dibakar dengan besi $2 \mathrm{X} 2$ cm yang sudah dipanaskan dengan kompor selama 2 menit. Lalu dibagi menjadi 5 kelompok yakni K1 (kontrol), K2 (pemberian madu 1x1), K3 (pemberian madu 3x1), K4 (pemberian nebacetin topikal gel 5gr 1x1), K45 (pemberian nebacetin topikal gel 5gr 3x1) dengan jumlah 5 ekor tikus setiap kelompoknya. Tikus tersebut akan diamati selama 15hari dengan menggunakan parameter panjang dan lebar luka yang dapat diukur dengan menggunakan penggaris dan jangka sorong.

\section{Hasil}

Aktifitas madu terhadap penyembuhan luka bakar dengan menggunakan metode topikal. Diamater zona luka dapat diukur dengan menggunakan penggaris dan jangka sorong. Hasil uji laboratorium dengan perlakuan kontrol, madu $1 \times 1$, madu $3 \times 1$, nebacetin topikal gel $5 \mathrm{gr} 1 \times 1$. Nebacetin topikal gel 5gr 3x1 didapatkan zona luka seperti yang tertera pada gambar dan tabel berikut.

Tabel 1. 16 Janurai 2019 (hari ke-1)

\begin{tabular}{cccccc}
\hline Ukur & Kontrol & Madu 1X1 & Madu 3X1 & Neba 1X1 & Neba3X1 \\
\hline $\mathrm{p} / 1$ & $18,3 / 12,4$ & $16,7 / 13,3$ & $17,5 / 16,2$ & $14,9 / 13,2$ & $12,7 / 9,4$ \\
$\mathrm{p} / 1$ & $17,8 / 13,1$ & $17,4 / 11,8$ & $16,4 / 15,2$ & $16,2 / 12,8$ & $14,7 / 14,2$ \\
$\mathrm{p} / 1$ & $14,6 / 12,3$ & $16,6 / 13,5$ & $16,1 / 13,6$ & $15,4 / 14$ & $16,1 / 15$ \\
$\mathrm{p} / 1$ & $19,2 / 13,7$ & $14,2 / 11,5$ & $16,4 / 15,3$ & $17,3 / 14,1$ & $15,6 / 14,9$ \\
$\mathrm{p} / 1$ & $16,6 / 12,9$ & $16,1 / 13,5$ & $16,4 / 14,5$ & $16,6 / 13,3$ & $16,4 / 15,3$ \\
\hline
\end{tabular}

Tabel 3. 22 Januari 2019 (hari ke 6)

\begin{tabular}{cccccc}
\hline Ukur & Kontrol & Madu 1X1 & Madu 3X1 & Neba 1X1 & Neba 3X1 \\
\hline p/l & $14,2 / 14,6$ & $12,2 / 14,1$ & $15,9 / 16,2$ & $14,4 / 17,1$ & $13,7 / 12,2$ \\
p/1 & $14,1 / 13,2$ & $10 / 14,5$ & $16,4 / 18,1$ & $15 / 13$ & $9,4 / 12$ \\
p/l & $8 / 9,8$ & $14,8 / 14,7$ & $14,7 / 15,8$ & $14,1 / 12,2$ & $10,6 / 11,5$ \\
p/1 & $13,3 / 8,9$ & $14,6 / 15,9$ & $16,1 / 17$ & $17,3 / 14,1$ & $14,6 / 14,5$ \\
p/1 & $14,1 / 12,4$ & $13,2 / 13,8$ & $18,7 / 17,6$ & $16,6 / 13,3$ & $10,1 / 15,1$ \\
\hline
\end{tabular}

Tabel 3. 28 Januari 2019 (hari ke 12)

\begin{tabular}{cccccc}
\hline Ukur & Kontrol & Madu 1X1 & Madu 3X1 & Neba 1X1 & Neba 3X1 \\
\hline p/l & $8,9 / 9,8$ & $10,3 / 7,3$ & $14,1 / 12,7$ & $10,9 / 6,9$ & $9,9 / 8,1$ \\
p/l & $12,6 / 7,4$ & $8,9 / 9,4$ & $11,5 / 13,6$ & $6,5 / 5,5$ & $13,5 / 10,8$ \\
p/l & $4,1 / 5,1$ & $9,9 / 9,3$ & $11,4 / 14,3$ & $9,3 / 8,8$ & $15,7 / 13,1$ \\
p/l & $11,5 / 6,1$ & $6,3 / 6,7$ & $10,4 / 14,3$ & $10,6 / 5,4$ & $13,5 / 14,9$ \\
p/l & $7,8 / 4,9$ & $8,1 / 7,2$ & $12,9 / 13,4$ & $11 / 8,6$ & $11,8 / 11,9$ \\
\hline
\end{tabular}

Keterangan:

p/l: panjang / lebar

neba: nebacetin 
Dari hasil yang telah didapatkan bahwa tikus yang dikenakan luka bakar dan diolesi oleh madu sekali sehari menunjukkan tingkat penyembuhan yang lebih cepat dibandingkan kelompok yang lain.
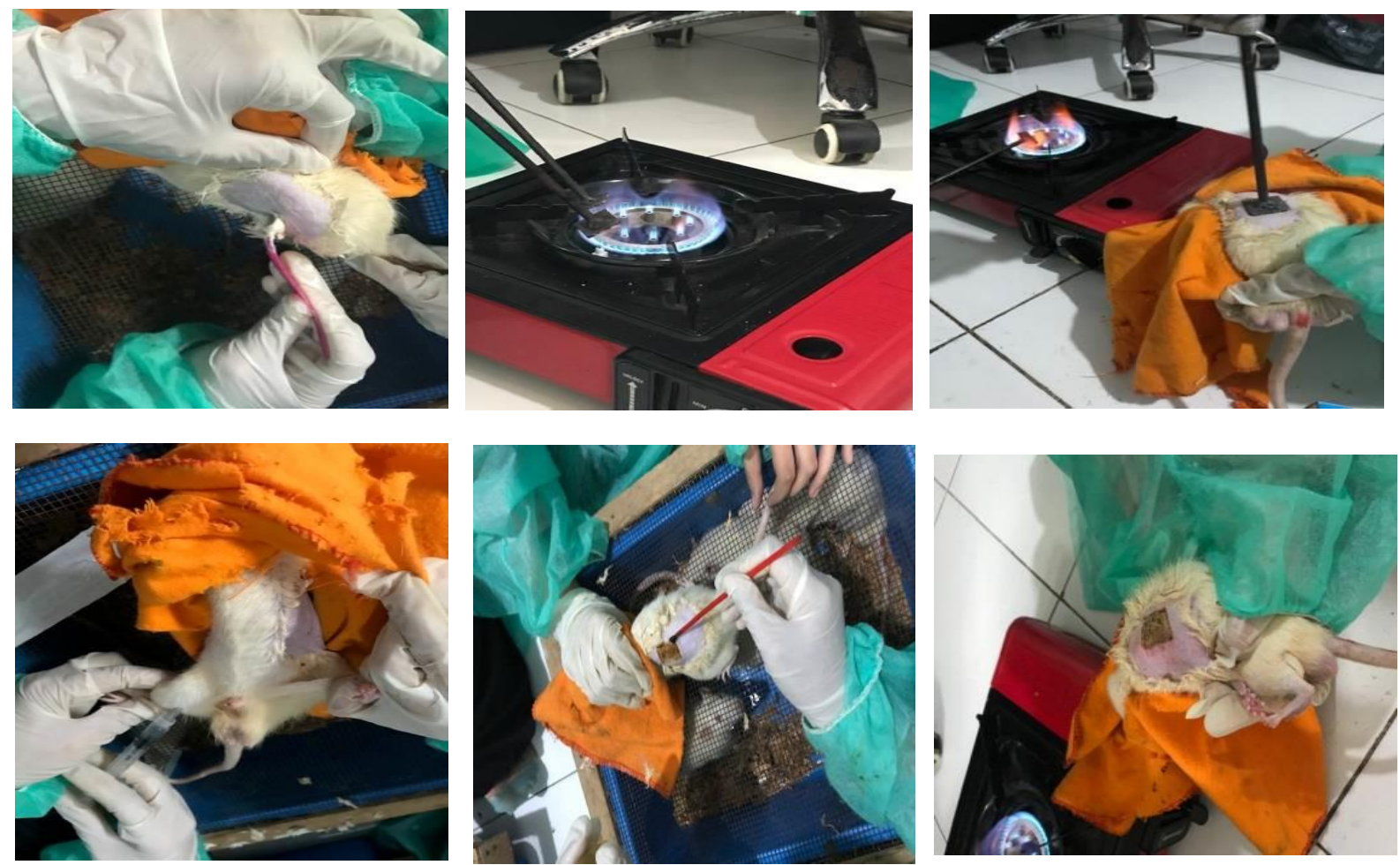

Gambar 1. Proses Percobaan luka bakar pada tikur dengan pemberian madu untuk penyembuhan

\section{Pembahasan}

Berdasarkan hasil penelitian yang diperoleh bahwa madu memiliki efektivitas terhadap penyembuhan luka bakar. Hal ini ditunjukkan dengan hasil penyembuhan luka pada kelompok kontrol 13 hari, madu 1x1 7 hari, madu 3x1 10hari, Nebacetin topikal gel 5gr 1x1 9hari, Nebacetin topikal gel 5gr 1x1 11hari.

Madu dapat digunakan sebagai terapi untuk luka bakar, infeksi, dan luka ulkus. Dunia kedokteran telah banyak membuktikan madu sebagai obat yang unggul ${ }^{9}$. Selain memiliki efek anti mikroba, madu juga memiliki efek anti inflamasi dan meningkatkan fibroblastik serta angioblastik $^{6}$. Analisis mengenai kandungan madu menyebutkan bahwa unsur terbesar komponen madu adalah glukosa dengan kadar fruktosa paling besar $(76,8 \%)$, disamping mineral dan vitamin ${ }^{7}$.

\section{Kesimpulan dan Saran}

Berdasarkan hasil dari penelitian yang dilakukan, maka bisa diambil kesimpulan bahwa Penyembuhan luka bakar pada tikus putih paling efektif dengan pemakaian madu 1X1, penyembuhan luka bakar pada tikus putih dengan memanfaatkan nebacetin topical 1X1 juga termasuk efektif, Penyembuhan luka bakar dengan menggunakan madu boleh digunakan oleh masyarakat sebagai pengganti obat tropikal dan lebih mudah didapat apabila tinggal di daerah pedalaman. 
Hendy, I Nyoman Erlich Lister. Tingkat Efektivitas Penyembuhan Luka Bakar Derajat IIA dengan Pemberian Madu dan Pemberian Salep Nebacetin pada Tikus Putih (Rattus Norvegicus)

DOI:

\section{Ucapan Terimakasih}

Penulis mengucapkan terima kasih kepada Rektor Universitas Prima Indonesia, Dr. Chrismis Novalinda Ginting, M.Kes, dan Dekan Fakultas Kedokteran dr. Linda Chiuman, M.K.M yang telah memfasilitasi laboratorium di Fakultas Kedokteran Universitas Prima Indonesia, kepala prodi serta kepala lab animal house di Fakultas Ilmu Pengetahuan Alam Universitas Sumatera Utara Prof. Dr. Syafruddin Ilyas, M. Biomed. Ucapan terimakasih juga dapat disampaikan kepada pembimbing utama Dr. dr. I Nyoman Enrich Lister. M.Kes dan tim analis Animal House Fakultas Matematika dan Ilmu Pengetahuan Alam Adi Gunawan S.Si yang turut membantu dalam pelaksanaan penelitian.

\section{Daftar Pustaka}

1. Kristanto, H. Perbedaan efektifitas perawatan luka bakar derajat II dengan lender lidah buaya dibandingkan cairan fisiologi dalam mempercepat proses penyembuhan. Malang: Fakultas Kedokteran Universitas Brawijaya; 2005

2. Bessey, P. Q., Caruso, D., Casavant, C., Edelman, L., Jeng, J., Kemalyan, N.,
Christopher. 2011. America burn association national burn repository 2011 . America Burn Association National Burn.

3. Wibawani, L., E. S. Wahyuni, dan Y. W. Utami. 2015. Pengaruh pemberian etanol daun melati secara topical kepada peningkatan kesembuhan luka bakar derajat IIA pada tikus putih .Majalah kesehatan FKUB. 2(4):196-206.

4. Ratnayani, K. Adhi, NMAD., Gitadewi, IGAMAS. 2008. Penentuan kadar glukosa dan fruktosa madu. Jurnal Kimia 2. Vol 2 No 2. hal 77-86.

5. Suranto, A. 2007. Terapi Madu. Jakarta.

6. Medhi B, Puri A. Topical application of honey in treatment of wound healing.

7. Aden R. Manfaat dan khasiat madu. Yogyakarta : Hanggar Kreator; 2010. P. $64 ; 92$

8. Yuliarti, N. 2015. Khasiat Madu untuk kesehatan dan kecantikan. Yogyakaarta: Andi

9. Suranto, A. Khasiat dan Manfaat Madu Herbal. Tangerang: Agromedia Pustaka; 2004. 